\title{
SALVADOR GARCÍA RAMÍREZ
}

\author{
La cronista de los vientos \\ With a commentary by Luciano García García \\ The Grove 25 (2018-2020)
}

Me asomo, como cada amanecer, a esta plazoleta diminuta

a la sombra rayada de la pérgola.

Adoro esta planicie, antesala

de una casa de puertas al poniente.

Aprecio este rellano, paralelo

al plano de las aguas que deslumbran

especialmente aquí, en esta tierra

estrecha donde todo se derrama

por los acantilados de los días.

Puestas están las sillas y la mesa.

¡Tantas generaciones se reunieron

junto a su ofrenda de vendimias! Quema

la luz las flores de los tiestos. Metros

más abajo se borra la emoción

de los retratos en las cruces. Mudo

permanece el teléfono. Aguarda

mientras cuido las eras de un recinto

que es tan solo horizonte, lejanía

y letargo y un rastro de equipaje

gastándose en las piedras. He quedado

para ser la cronista de los vientos,

ahora que se hundieron los molinos.

Traen escasa la lluvia los céfiros.

Bóreas fue benevolente. Nunca

me asomo a la bahía cuando vienen

los barcos. Mi velero es esta borda

de llana soledad donde persisto

sin más correspondencia que el recuerdo

que riego entre las rejas,

al resguardo del flash de los turistas. 
(Salvador García Ramírez, Periplos-Periploi. Edición bilingüe español-inglés. Traducción Luciano García García y Elizabeth Adama. Editorial Universitaria, Universidad de Jaén. De próxima aparición)

Periplos, como su propio nombre sugiere, es el viaje sentimental con escalas de un turista con sensibilidad a flor de piel que, como tantos otros y tan distintamente de tantos otros, se adentra en la experiencia del mundo griego en un viaje iniciático y sensitivo donde las distintas presencias de las islas y la península griega se superponen de una forma orgánica y singular. 


\title{
The chronicler of winds
}

\author{
With every dawn 1 look out \\ onto this tiny square \\ under the striped shade of pergolas. \\ 1 love this plain, this antechamber \\ of a house with doors facing east. \\ I love this landing, parallel \\ to the plane of the shining waters, \\ chiefly here, in this narrow \\ land where everything spills itself \\ over the cliffs of days. \\ The chairs and tables are settled \\ So many generations gathered \\ beside their vintage offering! The light \\ burns the flowers in the pots. Metres \\ below the emotion of the portraits \\ on the crosses blur to nothing. Mute \\ remains the telephone. It waits \\ while I look after the threshing floor \\ of a precinct which is only horizon \\ far-off distance and lethargy, and a trail of luggage, \\ wearing out on the stones. I have been left \\ only to be the chronicler of winds, \\ now that the windmills have collapsed. \\ Scant rain brings the zephyr. \\ Boreas was benevolent. I never \\ look onto the bay when the ships \\ return. My sailboat is this gunwail \\ of flat solitude where I persist \\ with only the correspondence of memories \\ which I water from behind the railings \\ sheltered from the tourists' flashes.
}

(Salvador García Ramírez, Periplos-Periploi. Bilingual edition Spanish-English. Translated Luciano García García and Elizabeth Adams. Editorial Universitaria, Universidad de Jaén. Forthcoming)

Periploi, as its name suggests, is the sentimental journey with stopovers of a tourist with acute sensitivity that, like so many others and so different from others, delves into the experience of the Greek world in an initiatory and sensitive journey where the different presences of the islands and the Greek peninsula overlap in an organic and unique way. 


\section{La cronista de los vientos: Un comentario}

Se trata de la única pieza del libro que cuenta una historia. En ella el yo poético cede la palabra a un personaje femenino que hablará en primera persona. El destino la ha condenado a pasar el final de sus días asomada al otero de una isla, habitando una casa en la que ya no queda nadie, en un lugar al que llegan y del que parte la gente en multitudes. Toda una ironía. Lo único que le queda es mantener el espacio, el volumen de su casa, en perfecto estado, dispuesto para cualquier posible visita. Mientras tanto, su única distracción es observar qué tipo de viento sopla cada día.

1-10. El poema comienza situando el escenario en que vive. El sitio es escaso en el lugar de privilegio que ocupa su casa asomada a un amplio horizonte. También los árboles y un pequeño jardín son un lujo en estas islas donde el agua escasea. Tener una pequeña plazoleta ante su casa, un pequeño regalo, es algo de lo que casi nadie dispone en un lugar tan estratégico. Su casa está orientada al atardecer, esos hermosos atardeceres del Egeo.

11-21. En el verso 5 se ha mencionado que la casa está orientada al poniente, posiblemente con unas magníficas vistas de la bahía de Santorini, pero también orientada, metafóricamente, al ocaso, el ocaso de una familia de la que, muertos o emigrados sus miembros, ya no queda nadie. El verso 11 ya sugiere unos preparativos mecánicos (la mesa siempre puesta) para una rutina diaria (el almuerzo familiar) que no se materializará ya más. El verso siguiente claramente nos presenta la lamentación por las generaciones perdidas y la nostalgia por las celebraciones familiares (la fiesta de la vendimia) (12-13). La soledad del patio se nos presenta, por medio de una imagen admirable: las flores deslumbrantes por el mismo celo desesperanzado de quien inútilmente prepara todos los días la mesa (13-14). Más abajo en la pendiente está el cementerio; allí los retratos de los familiares fallecidos insertos en las cruces o en las lápidas van desvaneciéndose. La emigración en estas islas ha sido un drama secular que, lejos de perderse, se ha ido acrecentando. La mujer espera en vano una llamada de teléfono de los parientes, quizá hijos o nietos de un país lejano (16-17). El aparato permanece silencioso mientras su casa, expuesta sobre el otero, no es más que una era, que ella sigue cuidando, un espacio vacío y desolado de tanto mirar el horizonte, que es sinónimo aquí de dispersión, lejanía y diáspora (17-21)

21-23. Se remarca aquí la idea del título. Solo le queda el oficio en la vida de ser la cronista de los vientos, esos vientos que, paradójicamente, ahora ya no tienen ninguna función por el declive de los molinos (21-23). Se enumeran esos vientos 
del Egeo de procedencia y naturaleza tan distintas. Cumpliendo con su oficio de cronista, nuestro personaje pasa a enumerar en un supuesto anuario los varios tipos de viento y su comportamiento, en un intento de simbolizar las estaciones, el paso del tiempo en la rueda imparable de los años (24-25).

25-31 Para finalizar, se resalta la renuncia, el toque trágico, tan griego. A nuestra cronista ni siquiera le queda la esperanza del regreso de alguien querido. Al contrario de la mujer del pescador, ella ha renunciado a ver venir los barcos (2527). Su único velero es esta borda sólida en la que se asoma su casa, esta atalaya anclada a un eterno lugar pero con el contraste de disponer de una enorme distancia a sus pies para viajar con la mirada. La única correspondencia que recibe son sus propios recuerdos que intenta mantener vivos. Por ellos persiste y se aísla detrás de sus plantas y su reja, ajena a la curiosidad de los turistas (27-31).

Según confiesa el propio autor, este hermoso poema era necesario. Para completar el poliedro de una visión de Grecia había que dedicar una cara al drama de la emigración, a la esencia, o maldición, del nomadismo. Condenados estamos —nos dice Salvador García Ramírez - al periplo desde el mismo momento en que nacemos y el tiempo nace con nosotros para recalcar nuestra mudanza.

\section{The Chronicler of Winds: A Commentary}

This is the only piece of the book that tells a story. The poetic self gives the word to a female character who will speak in the first person. Destiny has condemned her to spend the end of her days looking out from the hillock of an island, inhabiting a house where no one remains, located in a place, paradoxically, where people arrive and leave in crowds. Quite ironic. The only thing left for her is to keep the space, the volume of her home, in perfect condition, ready for any possible visit. Meanwhile, her only distraction is watching what kind of wind blows each day.

1-10. The poem begins by setting the stage in which she lives. The site is too narrow in the place of privilege where her house lies, overlooking a wide horizon. Trees and a small garden are also a luxury on these islands where water is scarce. Having a small square in front of your house is a little gift, something almost nobody has in such a strategic place. Her house is oriented towards sunset, towards those beautiful Aegean sunsets.

11-21. As has just been mentioned, the house is oriented to the west, possibly with magnificent views of the bay of Santorini. Metaphorically its orientation towards the sunset stands for the sunset of a family whose members have died or emigrated so that there is no one left. Line 11 already suggests some menial preparations (the 
table always set) for a daily routine (family lunch) that will no longer materialize. The following line explicitly presents the lamentation for lost generations and the nostalgia for the family or communal celebrations (the harvest festival) (12-13). The solitude of the yard is presented to us through an admirable image: the dazzling flowers looked after by the same hopeless zeal of those who uselessly prepare the table every day (13-14). Further down the slope lies the cemetery. There the portraits of the deceased relatives inserted into the crosses or on the tombstones are fading. Emigration on these islands has been a secular drama that, far from waning, has been increasing. The woman waits in vain for a phone call from relatives, perhaps children or grandchildren from a distant country (16-17). The device remains silent while her house, exposed to the elements on the hillock, is nothing more than a threshing floor, which she continues to care for, an empty and desolate space after so much looking at the horizon, which is synonymous here with dispersion, remoteness and diaspora (17-21).

21-23. The idea of the title is highlighted here. She only has the task in life to be the chronicler of the winds, those winds that, paradoxically, now no longer have any function due to the decline of the mills (21-23). The Aegean winds of such different origin and nature are listed. Fulfilling her job as a chronicler, our character goes on to enumerate in a supposed yearbook the various types of wind and their behaviour, in an attempt to symbolize the seasons, the passage of time in the unstoppable wheel of the years (24-25).

25-31 Finally, the resignation, a tragic touch so typically Greek is evoked. Our chronicler does not even have the hope of the return of someone dear. Unlike the fisherman's wife, she has given up seeing the ships coming back (25-27). Her only sailboat is this solid board on which her house lies and from which it looks out, this watchtower anchored to an eternal place, but with the contrast of having a vast distance at her feet to travel with her eyes. The only postal correspondence she receives is her own memories that she tries to keep alive. That is why she persists and keeps herself isolated, behind her plants and her iron fence, oblivious to the curiosity of tourists (27-31).

According to the author, this is a poem that was needed to round off the book. To complete a polyhedral vision of Greece it was highly necessary to dedicate one facet to the drama of emigration, to the essence or curse of nomadism. We are condemned - Salvador García Ramírez tells us - to our personal periplos from the moment we are born and time is born with us with the effect of emphasizing our mutability.

\section{Luciano Garcia Garcia}


Salvador García Ramírez (Rus, Jaén, 1958) ha sido profesor de física y director del Instituto Stma. Trinidad de Baeza (Jaén), ciudad donde reside. En la actualidad colabora con el Centro Andaluz de las Letras. Ha publicado los libros de poemas La hora del vigía (2000), Premio "El olivo" del ayuntamiento de Jaén; Ruradia: remota república (2002), ayuntamiento de Rus; Ríos de arena (2005), Premio Denia; Nudos (2006), Premio Alcalá de Henares; Tiempo de tranvías / O tempo dos eléctricos (2016), editado en Lisboa en español y portugués; Arca del agua (2018), Diputación de Jaén; La casa (2019), Premio “Carmen Merchán”; Rayas y puentes / Raias e pontes (2020), libro bilingüe premiado en Cáceres; y Entretiempos (2020), Premio Noches Poéticas de Bilbao. Ha recibido también el Premio de las Justas Literarias de Reinosa (2018), el Premio "Facultad" de la Universidad de Jaén (2019) y el premio "Juan Bernier" del Ateneo de Córdoba por su poemario Punto y aparte (2020). Como profesor de física ha participado en la publicación La luz, un incesante flujo de fotones (1995) y como divulgador ha colaborado en el catálogo Los caracoles de Rus (2018). 
